\title{
Potasyum Borhidrit Hidroliz Reaksiyonu İçin Ni-B-P Katalizörünün Kinetik Özellikleri
}

\author{
Mehmet Salih KESKİN ${ }^{1}$, Mehmet Salih AĞIRTAȘ ${ }^{2}$, Orhan BAYTAR ${ }^{3}$ \\ Mehmet Sait IZGI' ${ }^{3}$, Ömer ŞAHİN ${ }^{3 *}$ \\ ${ }^{1}$ Siirt Üniversitesi Eğitim Fakültesi, Fen Bilgisi Bölümü \\ ${ }^{2}$ Yüzüncü Yll Üniversitesi Fen Fakültesi, Kimya Bölümü \\ ${ }^{3}$ Siirt Üniversitesi Mühendislik Fakültesi, Kimya Mühendisliği Bölümü \\ (ORCID:0000-0001-9862-1590) (ORCID: 0000-0003-1296-2066) (ORCID: 0000-0002-2915-202X) \\ (ORCID: 0000-0003-3685-3219) (ORCID: 0000-0003-4575-3762)
}

\begin{abstract}
$\ddot{O} \mathbf{z}$
$\mathrm{Bu}$ çalışmada potasyum bor hidrür hidrolizindeki hidrojen üretimi için yüksek performanslı Ni-B-P katalizörü sentezlenmiştir. Bilindiği üzere katalizörler kimya endüstrisinde gerçekleştirilen çoğu reaksiyonlarda kullanılırlar. Burada analitik yöntemle katalizörün, BET, XRD ve SEM analizleri yapılarak katalizörün karakteristik özellikleri belirlendi. Ayrıca $\mathrm{Ni}_{2} \mathrm{P}$ katalizörünün potasyum bor hidrolizi için; en iyi $\mathrm{Ni} / \mathrm{P}$ oranı, optimum $\mathrm{KOH}$ konsantrasyonu, KBH4 konsantrasyonu, katalizör miktarı ve kinetiksel parametreler için farklı sıcaklıklardaki etkisi incelendi. Katalizörün hidrojen üretim hızının $665 \mathrm{~mL} / \mathrm{dak}^{*} \mathrm{~g}$, en iyi Ni/P oranının 0.184 olarak belirlendi. Ayrıca reaksiyon hız mertebesi $\mathrm{n}$ - dereceden 0.25 olarak belirlendi, buna bağlı olarak ta arhenius eşitliğinden aktivasyon enerjisinin değeri $58,528 \mathrm{~kJ} / \mathrm{mol}$ olarak bulunmuştur.
\end{abstract}

Anahtar kelimeler: $\mathrm{Ni}_{2} \mathrm{P}$, Katalizör, Hidrojen, Potasyum Borhidrür, Hidroliz.

\section{Kinetic Properties of Ni-B-P Catalyst for Potassium Borohydride Hydrolysis Reaction}

\begin{abstract}
For the production of hydrogen in the hydrolysis of potassium boron hydride of this product, a high performance Ni-B-P catalyst was synthesized. Catalysts in the unknown state of the chemical industry FTIR, EDS, XRD and SEM analyzes of the catalysts were used to determine the characteristics of the catalysts. Also for potassium boron hydrolysis of Ni2P catalyst; The best Ni / P ratio, optimum $\mathrm{KOH}$ concentration, KBH4 concentration, catalyst capacity and kinetic parameters were investigated at different temperatures. The hydrogen production rate of the catalyst was determined to be $665 \mathrm{~mL} / \mathrm{min} * \mathrm{~g}$ and the best $\mathrm{Ni} / \mathrm{P}$ ratio was 0.184 . In addition, the reaction rate range $\mathrm{n}$ was determined to be 0.2 degrees, so the activation energy value in the arhenius equation was $58,528 \mathrm{~kJ} /$ mol.
\end{abstract}

Keywords: $\mathrm{Ni}_{2} \mathrm{P}$, Catalyst, Hydrogen, Potassium Borohydride, Hydrolysis.

\section{Giriş}

Son yıllarda küresel anlamda enerji talebi gelecekte öngörülemeyecek oranda artacağı düşünülmektedir [1]. Bununla birlikte fosil yakıtlar hem çevreyi kirletmekle beraber gitgide azalmaktadır. Bu yüzden alternatif temiz ve çevreci yakıtlara ihtiyaç duyulmaktadır. Hidrojen fosil yakıtlara nazaran daha çevreci ve yüksek enerji yoğunluğuna sahip olduğundan dolayı, alternatif temiz enerji kaynağıdır. Yani sürdürülebilir temiz enerji fosil yakıtların zararlı etkisinden dolayı önemli bir yere sahiptir [2, 3].

Hidrojenin yan ürünü sadece su buharı olduğundan dolayı çevrecidir. Yani içten yanmalı motorlarda kullanıldığı zaman hava kirliliği açısından olumlu etki yapar. Buna bağlı olarak hidrojenin

\footnotetext{
"Sorumlu yazar: omersahin@siirt.edu.tr

Geliş Tarihi: 24.09.2019, Kabul Tarihi: 08.04.2020
} 
düşük yoğunluğa sahip olmasından ötürü gaz halinde depolanması zordur, bunun içinde sıkıştırılmış olması gerekir. Bunun içinde çok yüksek basınç altında taşınmasının riskli olması ve maliyet açısından olumsuz etkiye sahiptir. Bu yüzden yüksek hidrojen depolama yeteneğine sahip enerji kaynaklarına yönelmek gerekir. Son yıllarda yüksek hidrojen depolama yeteneğine sahip olan kimyasal hidritlerden $\mathrm{NaBH}_{4}$ [4-6], $\mathrm{NH}_{3} \mathrm{BH}_{3}$ [7-9], $\mathrm{NaAlH}_{4}$ [10], oda sicaklığında hidroliz yoluyla hidrojen üretimine yönelik çalışmalar yapılmaya başlanılmıştır.

Bilindiği üzere bor hidrürlerden hidrojen eldesinde uygun ve kullanışlı bir katalizör önemli rol oynamaktadır. Sulu ortamda kendiliğinden bozunmaktadırlar. Genellikle bu tür kimyasal hidritler için heterojen katalizörler kullanılır [11-16]. Aynı şekilde son yapılan çalışmalarda katalizörlerin, yüzey alanını artırmak için katalizörler destek malzemeleri üzerine tutturularak katalitik aktiviteleri arttırılmıştır [17-22].

Şimdiye kadar $\mathrm{NaBH}_{4}, \mathrm{NH}_{3} \mathrm{BH}_{3}$ ile çok çalışma yapılmasına karşın $\mathrm{KBH}_{4}$ ile pek fazla bir çalışma yapılmamıştır. Bunun en önemli nedenleri ise potasyum bor hidrürün düşük hidrojen yoğunluğuna sahip olmasından kaynaklanmaktadır. Ancak KBH4 diğer bor hidrürlere nazaran hidroliz sırasında açığa çıkan 1sı daha az olduğundan dolayı reaktör tasarımı için önemlidir.

Bu çalışmada daha önce potasyum bor hidrür hidrolizinde kullanılmayan Ni-B-P katalizörü sentezlenmiştir. Bu katalizörün Ni/P oranı, en uygun $\mathrm{KOH}$ oranı, farklı katalizör miktarlarının potasyum bor hidrür hidrolizine etkisi, farklı potasyum bor hidrür konsantrasyonlarının etkisi ve farklı sicaklıkların potasyum bor hidrür hidrolizine etkileri ayrı ayrı incelendi. Ayrıca reaksiyonun derecesi ve aktivasyon enerjisi de hesaplandi.

\section{Materyal ve Metot}

$40 \mathrm{~mL}$ saf suda $\mathrm{Ni}\left(\mathrm{NO}_{3}\right)_{2} 6 \mathrm{H}_{2} \mathrm{O}$ ve $\left(\mathrm{NH}_{4}\right)_{3} \mathrm{PO}_{4}$ metalleri çözdürüldükten sonra buz banyosunda $\left(0-5{ }^{\circ} \mathrm{C}\right)$ derece aralığına gelene kadar 600 rpm'de karıştırıldı. $40 \mathrm{~mL}$ saf suda $0.75 \mathrm{~g} \mathrm{NaBH}_{4}$ çözdürülüp buz banyosunda bulunan metal karışımı üzerine damla damla ilave edildi. Reaksiyon sonunda siyah bir çökelek olarak katalizörler elde edildi. Elde edilen katalizör süzülüp etanol ve birkaç kez saf su ile yıkandıktan sonra $80^{\circ} \mathrm{C}$ 'de azot gazı ortamında 2 saat kurutuldu. $\mathrm{KBH}_{4}$ hidrolizinde kullanmak üzere kapalı bir kapta muhafaza edildi.

\section{Bulgular ve Tartışma}

\subsection{Ni/P Mol Fraksiyonunun Etkisi}

$\mathrm{Ni}\left(\mathrm{NO}_{3}\right)_{2} \cdot 6 \mathrm{H}_{2} \mathrm{O}$ ve $\left(\mathrm{NH}_{4}\right)_{3} \mathrm{PO}_{4}$ bileşiklerini kullanarak farklı miktarlarda $\mathrm{Ni}$ ve $\mathrm{P}$ içeren karışımlar hazırlandıktan sonra $\mathrm{NaBH}_{4}$ ile indirgendi ve azot ortamında kurutulduktan sonra elde edilen katalizörler $30{ }^{\circ} \mathrm{C}$ 'de, $\% 2 \mathrm{KBH}_{4}, \% 2,5 \mathrm{KOH}$ ve $10 \mathrm{~mL}$ içeren çözeti potasyum borhidrür hidrolizinde kullanılmış ve hidroliz sonucu elde edilen hidrojen hacminin ve hidrojen başlangıç üretim hızının zamanla değişimleri Şekil 1'de verilmiştir.

Şekil 1'de görüldüğ̈̈ gibi farklı Ni/P mol fraksiyonu kullanıldığında katalizör içerisindeki nikel oranı arttıkça katalizörün $\mathrm{KBH}_{4}$ hidrolizindeki katalitik etkisini azaltmaktadır. Katalizör yapısındaki $\mathrm{Ni} / \mathrm{P}$ mol fraksiyonu 0.184 olduğunda optimum bir katalitik etkin değer yakalamaktadir. Ni/P mol fraksiyonu 0.184 olduğunda 25 dakikada $370 \mathrm{~mL}$ hidrojen gazı elde edilirken ,katalizör içerisindeki nikel miktarı 0.53 olduğunda ise 30 dakikada $350 \mathrm{~mL}$ hidrojen elde edilmektedir. Daha yüksek konsantrasyonlarda nikel içeren katalizörlerde hidroliz olayı çok daha uzun süre tamamlanmaktadır.

Şekil 1'in içerisine yerleştirilmiş olan hidrojen başlangıç üretim hızları Ni/P mol fraksiyon değişimi verilmiştir. Şekilde görüldüğü gibi katalizör içerisindeki Ni/P mol fraksiyonu 0.184 değerine kadar hidrojen başlangıç hızlarında bir artış, fakat daha yüksek miktarda nikel içeren katalizörlerde ise hidrojen üretim hızında bir düşüş olduğu görülmekte. Bu durumda tüm sonuçlara göre Ni-P-B katalizörünün KBH4 hidrolizinde kullanılması için en uygun katalizör 0.184 mol fraksiyon oranında nikel içeren katalizör olduğu belirlenmiştir. 


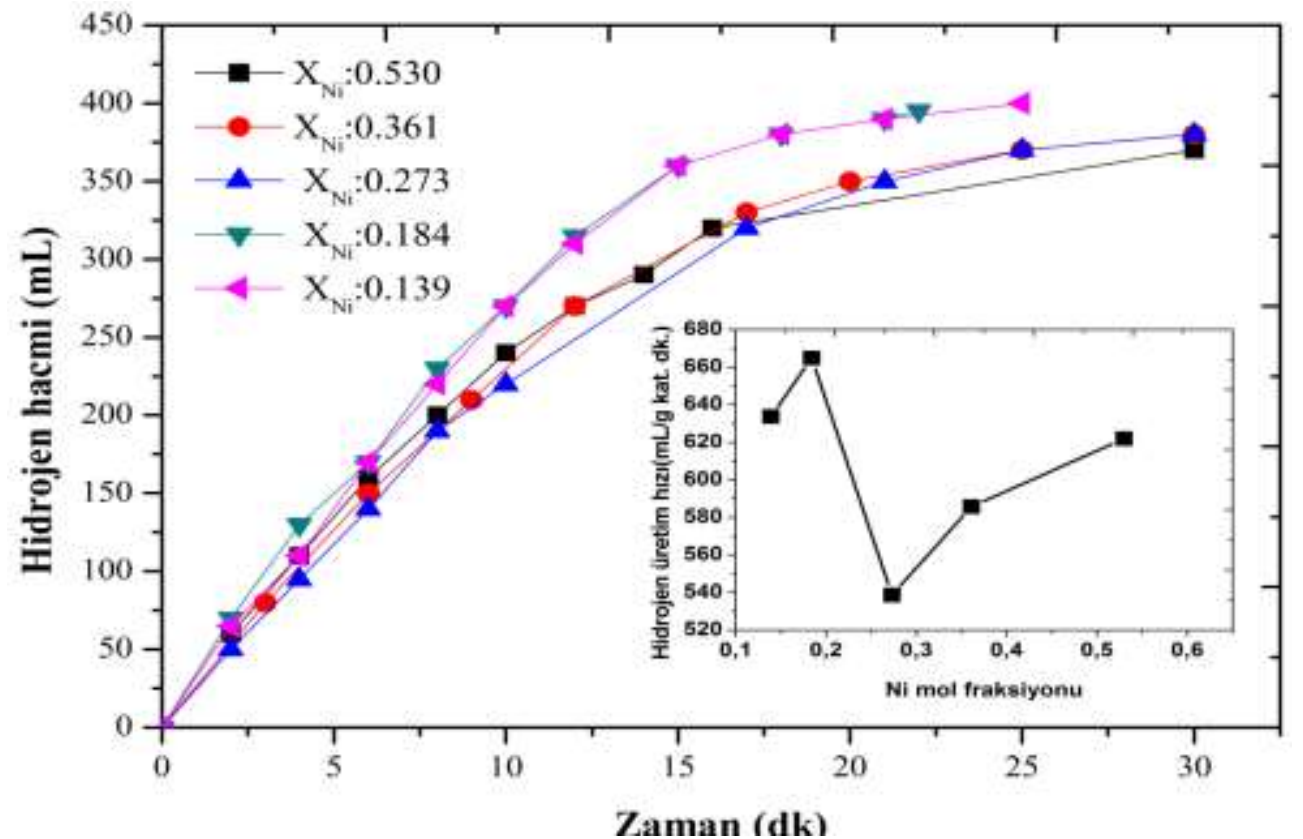

Şekil 1. Farklı Ni/P mol fraksiyona sahip katalizörlerin potasyum borhidrür hidrolizi ile elde edilen hidrojen hacminin zamanla değişimi ve hidrojen başlangıç üretim hızlarının mol fraksiyonu ile değişimi.

\subsection{KOH Konsantrasyonunun Etkisi}

Daha önce ifade edildiği gibi $\mathrm{KBH}_{4}$ sulu çözeltilerinde kararlı olmayıp kendiliğinden bozularak $\mathrm{H}_{2}$ gazını açığa çıkarmaktalar. $\mathrm{KBH}_{4}$ çözeltisinin stabilizesini sağlamak için çözelti ortamına $\mathrm{KOH}$ ilave edilerek pH'ı artırılmak ve böylece serbest $\mathrm{H}_{2} \mathrm{O}$ moleküllerinin sayısını azaltmasını sağlamakta, bunun sonucu olarak bor hidrürlerin kendiliğinden hidroliz olmaları engellenmektedir. Tez çalışmamızın bu kısmında Ni-P-B katalizörü varlığında $\mathrm{KBH}_{4}$ hidrolizin en iyi gerçekleştiği $\mathrm{KOH}$ konsantrasyonu belirlenmek için. $30^{\circ} \mathrm{C}$ 'de, $10 \mathrm{~mL}$ çözelti ve $50 \mathrm{mg}$. katalizör şartlarında $\% 2.5, \% 5, \% 7.5$ ve $\% 10 \mathrm{KOH}$ ilave edilerek, Ni-P-B katalizör ortamında açığa çıkan $\mathrm{H}_{2}$ gaz hacminin değişimi zamana bağlı olarak incelenmiş ve elde edilen sonuçlar Şekil 2'de verilmiştir. Aynı şekil içerisinde hidrojen başlangıç üretim hızları $\mathrm{KOH}$ konsantrasyonuna bağlı olarak değişimi verilmiştir.

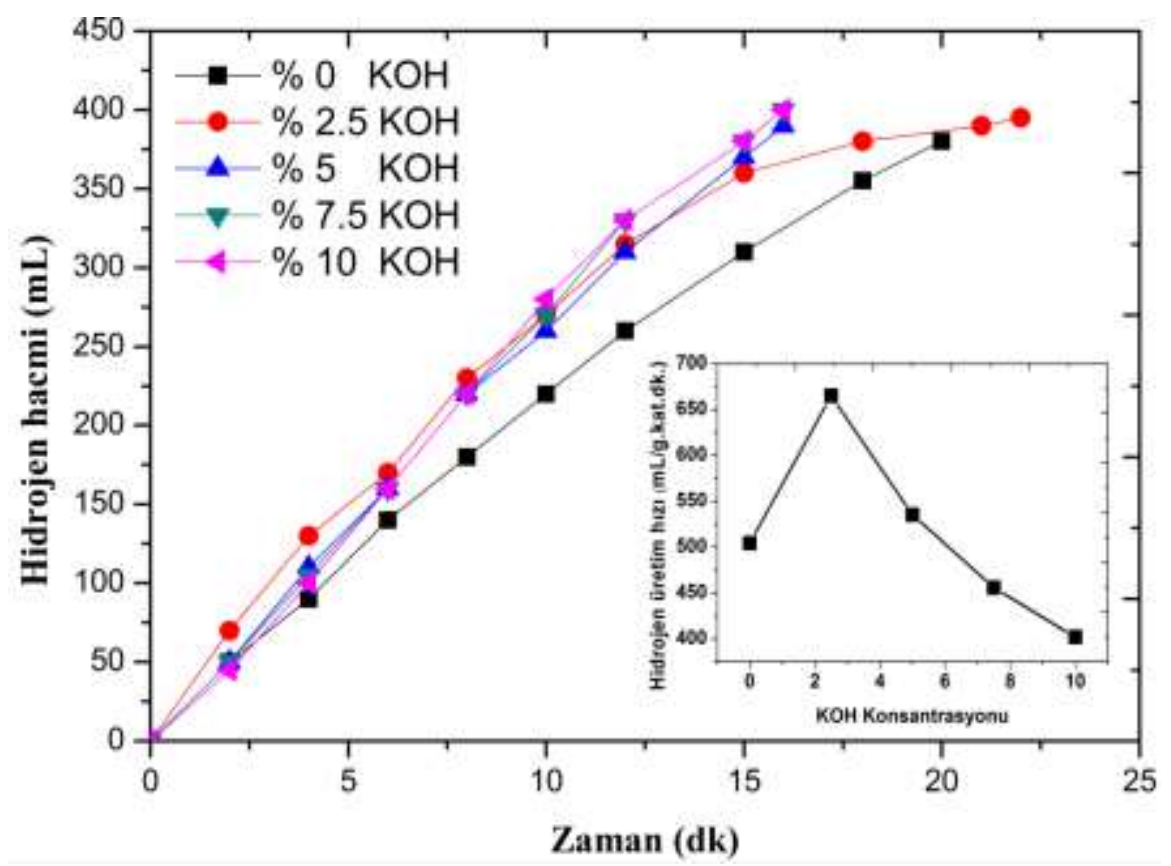

Şekil 2. Farklı potasyum hidroksit konsantrasyonlarda ve Ni-P-B katalizörü varlı̆̆ında açığa çıkan $\mathrm{H}_{2}$ gaz hacminin zamanla değiş̧imi ve hidrojen üretim başlangıç hızının KOH konsantrasyonuna bağlı olarak değişimi 
Şekil 2'de görüldügü gibi $\mathrm{KBH}_{4}$ hidrolizine $\mathrm{KOH}$ konulmadığı zaman hidroliz olayı yavaş da olsa kendiliğinden gerçekleşmektedir. Çözelti ortamında \%2.5 ile \%10 oranlarında $\mathrm{KOH}$ konulduğunda ise $\mathrm{KBH}_{4}$ kararlı hale gelerek kendiliğinde bozulmanın tamamen durduğu görülmektedir. Ni-P-B katalizörünü kullanarak KBH4 hidroliz reaksiyonu kontrollü bir şekilde gerçekleşmektedir. Şekil 2'nin içerisine yerleştirilen hidrojen başlangıç üretim hızlarının $\mathrm{KOH}$ konsantrasyonunu ile değişimindeki davranışı, farklı $\mathrm{KOH}$ konsantrasyonu varlığında hidrojen hacminin zamanla değişim davranışını destekler niteliktedir.

Şekil 2'de KOH konsantrasyonun \%0'den \%2.5'e arttırıldığında hidrojen başlangıç üretim hızının arttığı, daha yüksek KOH konsantrasyonlarda ise azaldığı görülmektedir. Örneğin ortamda KOH olmadığında hidrojen başlangıç üretim hızının $504 \mathrm{~mL} / \mathrm{dk}$.kat.g. iken ortamda $\% 2.5 \mathrm{KOH}$ olduğunda ise $664.4 \mathrm{~mL} \mathrm{H}_{2}$ /dk.kat.g. olduğu ve ortamda $\% 5 \mathrm{KOH}$ olduğunda ise $595 \mathrm{~mL} \mathrm{H} / \mathrm{dk}$. g kat. olduğu belirlenmiştir. $\mathrm{Bu}$ durumun muhtemel nedeni çözelti ortamındaki $\mathrm{OH}^{-}$iyonlarının konsantrasyonunun artması sonucu katalizörün $\mathrm{KBH}_{4}$ ile etkileşimini azalttığı yani sterik etki yaptığı düşünülmektedir. Diğer bir neden ise yüksek $\mathrm{pH}$ değerlerinde $\mathrm{KBH}_{4}$ hidrolizi sonucu oluşan potasyum metaboratın çözünürlüğünün artması sonucu çözelti ortamında bulunan potasyum metaboratın katalizörün aktif bölgelerine çökerek katalizör aktivitesi azalttığı düşünülmektedir. Elde edilen sonuçlar 1şığında Ni-P-B katalizörü kullanıldığında, $\mathrm{KBH}_{4}$ hidrolizine etki eden diğer parametreler incelenirken çözelti ortamında $\% 2.5 \mathrm{KOH}$ varlığında çalışıldı.

\subsection{Katalizör Miktarı Etkisi}

Daha öncede ifade edildiği gibi $\mathrm{KBH}_{4}$ kararlı olmayıp yavaş bir şekilde de olsa kendiliğinden hidrolize uğramakta, katalizör varlığında ise tepkime kontrollü bir şekilde gerçekleşmektedir. $\mathrm{Bu}$ nedenle kullanılan katalizör miktarına göre hidrolizin incelenmesi önem arz etmektedir. Katalizör miktarı etkisinin incelendiği çalışmalar $30^{\circ} \mathrm{C}$ 'de,$\% 2 \mathrm{KBH}_{4}$ ile $\% 2.5 \mathrm{KOH}$ içeren $10 \mathrm{~mL}$ çözelti kullanılarak farklı miktarlarda katalizör varlığında gerçekleştirilmiş ve elde edilen sonuçlar Şekil 3 'te verilmiştir.

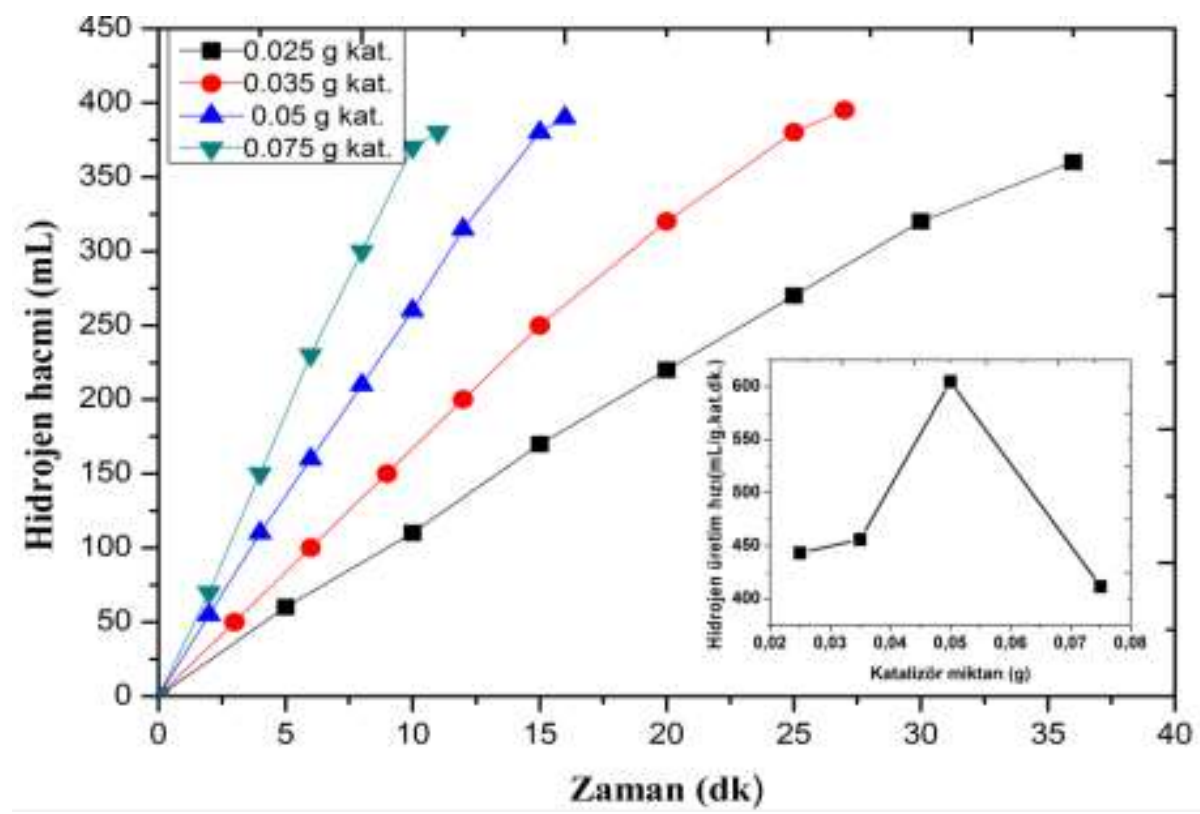

Şekil 3. Farklı miktarlarda Ni-B-P katalizörü varlığında $\mathrm{H}_{2}$ hacminin zamanla değişimi ve hidrojen başlangıç üretim hızlarının katalizör miktarına bağlı olarak değişimi

Şekil 3'de görüldüğü gibi çözelti ortamında katalizör miktarı arttıkça ayni miktar hidrojen üretmek için daha kısa sürede hidrolizin sonlandığı görülmekte. Bunun nedeni katalizör miktarı artıkça yüzey alanını genişlemesi ve buna bağlı olarak aktif bölgelerin artması ile ilgilidir. Örneğin; $0.025 \mathrm{~g}$ katalizör varlığında $\% 2 \mathrm{KBH}_{4}$ içeren çözelti hidrolizi 35 dakikada tamamlanırken ayni şartlarda 0.075 g katalizör kullanıldığında 11 dakikada tamamlanmıştır. Sonuç olarak $\mathrm{KBH}_{4}$ hidrolizi bazik olmayan ortamda her ne kadar kendiliğinden yavaş bir şekilde bozularak gerçekleşiyor olsa da katalizör 
varlığında hidrojen çıkışının oldukça hızlanması reaksiyondaki katalizörün önemli rol oynadığının göstergesidir.

Şekil 3'ün içerisine başlangıç hidrojen üretim hızlarının katalizör miktarına bağlı olarak değişimi verilmiştir. Bu şekle bakıldığında 0.025 gram katalizör ile 0.05 gram katalizör arasındaki hidrojen üretim hızlarının arttığı ve 0.05 'te $600 \mathrm{~mL} \mathrm{H}$ /g.kat. dk değerine vardığı ve daha yüksek katalizör miktarında ise hızlı bir şekilde düştügü görülmekte, bu durum daha önce ifade edildiği gibi katalizör miktarı artıkça reaksiyonun daha kısa sürede bittiği ifadesi ile örtüşmediği gibi görülse de (Y) eksenindeki birimlere bakıldığında bundan bir çelişkinin olmadığı görülür. Zira hidrojen başlangıç üretin hızlarının birim zamanla birim katalizör miktarı tarafından üretilen hidrojen hacmi olması sebebi ile grafiklerde farklı görünmesi normaldir. Bu davranışın temel nedeni daha önce ifade edildiği gibi katalizör miktarı artıkça aktif bölgeler de artmakta fakat hidrolizde etkin olan çözelti konsantrasyonundaki iyon sayısı ve difizyonun da aktif bölgeleri maksimum kullanılmasının karşılanması ile de ilgilidir. Yani katalitik bir reaksiyonda ürün verimine etki eden çözelti konsanrasyonu katı-sıvı ara yüzey tabakasının kalınlığı ve katalizör yüzeyindeki aktif bölgelerin sayısı ve kullanılması gibi bütün parametreler göz önüne alınarak değerlendirilmesi gerekmektedir.

\subsection{KBH4 Konsantrasyonu Etkisi}

Enerji taşıyıcı olarak $\mathrm{KBH}_{4}$ kullanıldığı göz önüne alındığında çözeltideki $\mathrm{KBH}_{4}$ konsantrasyonu ne kadar yüksek olursa daha çok istenen bir durumdur. Fakat $\mathrm{KBH}_{4}$ konsantrasyonu artıkça katalizörün katalitik verimini etkiler. Örneğin: $\mathrm{KBH}_{4}$ katalizör varlı̆̆ında hidroliz olduğunda çözünürlüğü daha düşük olan ürün (potasyum meta borat) katalizör yüzeyine çökmekte ve katalizörün aktif bölgelerini kapatabilmektedir. $\mathrm{Bu}$ nedenle farklı konsantrasyonlarda potasyum bor hidrür varlığında Ni-P-B katalizörün aktivitesini incelemek önem arz etmektedir. Farkl1 $\mathrm{KBH}_{4}$ konsantrasyonların etkisinin incelendiği deneyler $30^{\circ} \mathrm{C}$ 'de $10 \mathrm{ml}$. çözelti, $\% 2.5 \mathrm{KOH}$ ve farklı konsantrasyonlarda $\mathrm{KBH}_{4}$ içeren çözeltiler, $0.05 \mathrm{~g}$ NiPB katalizör varlığında gerçekleştirilen hidroliz sonucu elde edilen hidrojen gaz hacminin zamanla değişimi Şekil 4'te verilmiştir.

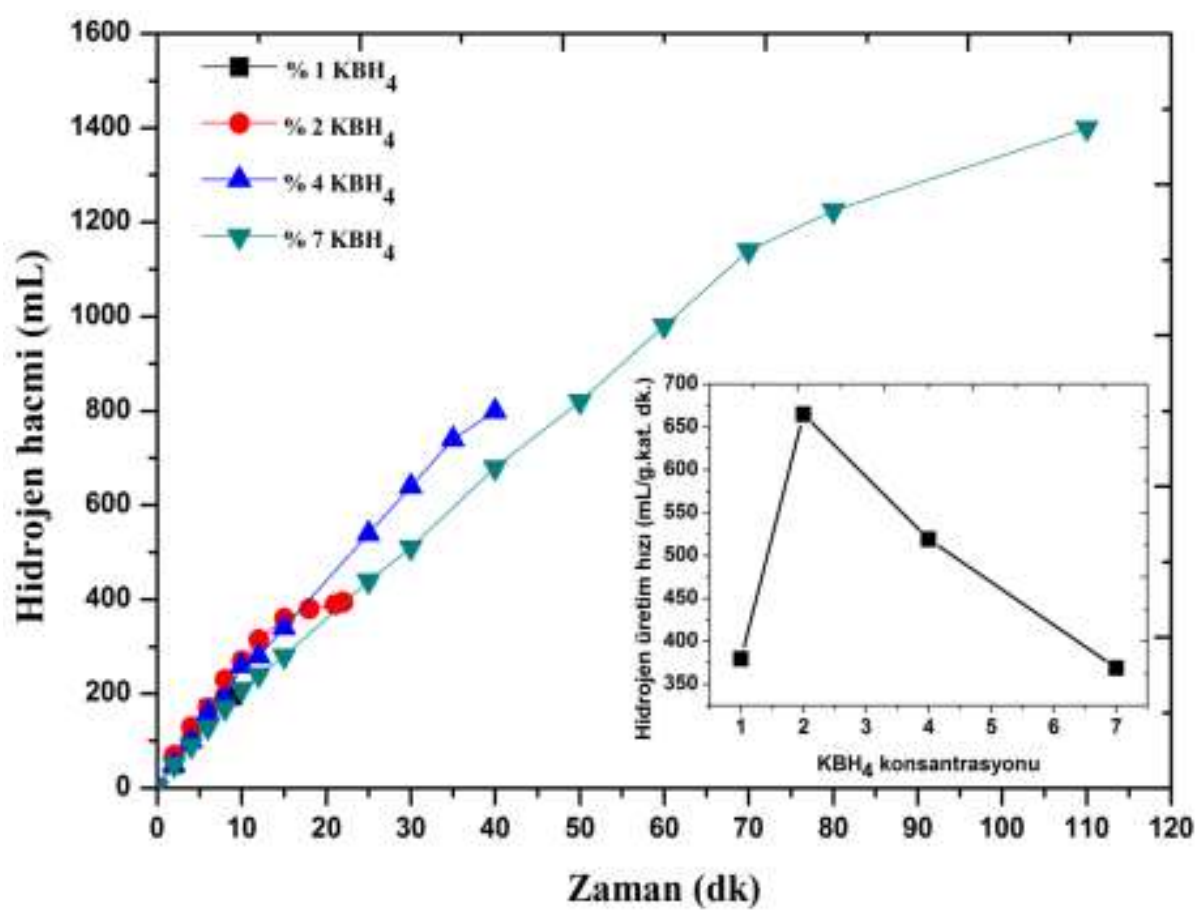

Şekil 4. Farklı $\mathrm{KBH}_{4}$ konsantrasyonlara sahip çözeltilerin Ni-P-B katalizörü varlığında hidrolizi sonucu ortaya çıkan $\mathrm{H}_{2}$ hacminin zamanla değişimi ve hidrojen başlangıç üretim hızlarının $\% \mathrm{KBH}_{4}$ konsantrasyonuna bağlı olarak değişimi.

Şekil 4'te görüldügü gibi $\mathrm{KBH}_{4}$ konsantrasyonu \%1'den \%7'ye geçerken hidroliz hızı sürekli azalmaktadır. Örneğin; \%4 $\mathrm{KBH}_{4}$ konsantrasyonunda 40 dakikada $\mathrm{KBH}_{4}$ hidrolizinde $800 \mathrm{ml}$ hidrojen gazı açığa çıkarırken, $\% 7 \mathrm{KBH}_{4}$ konsantrasyonunda 40 dakikada $680 \mathrm{ml}$ hidrojen gazı açığa çıkmıştır. 
Daha önce ifade edildiği gibi bunun muhtemel nedeni oluşan potasyum meta boratın katalizör yüzeyine çökmesi veya diğer bir neden olarak da çözelti ortamından $\mathrm{KBH}_{4}$ konsantrasyonu artıkça çözeltinin viskozitesinin artması ve bunun sonucu olarak moleküllerin hareketinin yavaşlamasından kaynaklandığını söylenebilir. Aynı zamana da $\mathrm{KBH}_{4}$ miktarı artıkça yukardan aşağı doğru doğrusala yakın bir düşüşü görmek mümkün. Şekil 4.içerisine yerleştirilen hidrojen üretim hızlarının $\mathrm{KBH}_{4}$ konsantrasyon değişiminde görüleceği gibi \%2.5 varlığında maksimuma, daha yüksek $\mathrm{KBH}_{4}$ konsantrasyonlarda ise hidrojen başlangıç üretim hızı $650 \mathrm{~mL} \mathrm{H} / \mathrm{g}$. kat. dk. değerinden $350 \mathrm{~mL} \cdot \mathrm{H}_{2} / \mathrm{g}$. Kat.dk. değerine kadar düşmektedir. Bunun muhtemel nedeni her ne kadar çözeltide oluşan potasyum borat konsantrasyonu ve çözelti vizkozitesine bağlı olsa da unutmaması gereken diğer bir husus ise çözelti ortamında bulunan sabit miktardaki katalizörden kaynaklanmaktadır. $\mathrm{Bu}$ durum şöyle açıklanabilir, çözeltideki $\mathrm{KBH}_{4}$ konsantrasyonu artıkça katalizör üzerine transfer olan $\mathrm{BH}_{4}{ }^{-}$anyonların miktarı da artacak katalizör miktarı sabit olduğu için aktif katalitik bölgeler de sabit olup reaksiyonun gerçekleşmesi için $\mathrm{KBH}_{4}$ katalizör yüzeyine gelen $\mathrm{BH}_{4}{ }^{-}$anyonlarını karşılayamayacaktır.

\subsection{Sıcaklık Etkisi}

Kimyasal bir reaksiyonda, katalitik olsun veya olmasin en önemli parametrelerden bir tanesi de reaksiyonun gerçekleştiği ortamın sıcaklığıdır. Bu amaçla Ni-P-B katalizör varlığında \%2 $\mathrm{KBH}_{4}$ ve $\% 2.5 \mathrm{KOH}$ içeren çözeltinin $0.05 \mathrm{~g}$ katalizör miktarı ile farklı sıcaklıklardaki hidroliz sonucu açığa çıkan $\mathrm{H}_{2}$ gaz hacimlerinin zamanla değişimi Şekil 5 'te verilmiştir. Sıcaklığın $\mathrm{KBH}_{4}$ 'in hidrolizine etkinliğini görmek amacı ile Şekil 5'te dikkat edilmesi gerek bir hususta $\mathrm{KBH}_{4}$ 'den NiPB katalizörü varlığında hidrojen üretimi yakıt pilinde kullanılmak isteniyorsa $40^{\circ} \mathrm{C}$ 'nin üzerindeki sıcaklıklarda çalışılması daha uygun olacaktır. Çünkü zamana bağlı olarak elde edilen hidrojen hacimleri hemen hemen sabit olup yakıt pilinde üretilen enerjinin kararlılığı açısında önem arz etmektedir. Şekil 5 içerisinde ise başlangıç hidrojen üretim hızları zamanla değişimi verilmiştir. Şekilde görüldüğü gibi başlangıç üretim hızların sıcaklıkla değişimi doğrusal olmayıp sıcaklığın artışı ile birlikte üstel olarak bir davranış göstermektedir.

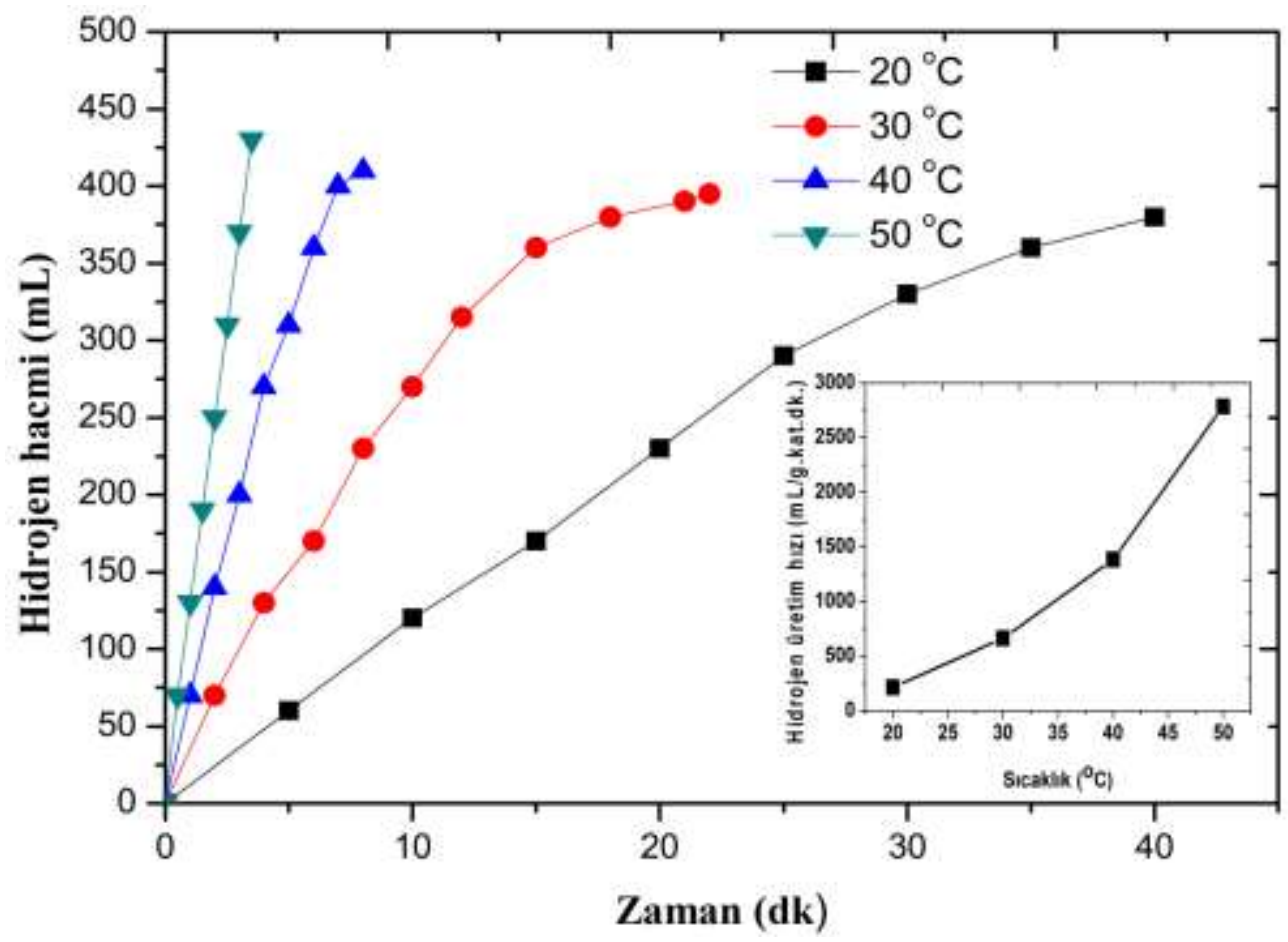

Şekil 5. Farklı sıcaklıklarda Ni-P-B Katalizör varlığında $\mathrm{KBH}_{4}$ hidroliz sonucu açığa çıkan $\mathrm{H}_{2}$ gaz hacminin zamanla değişimi ve hidrojen başlangıç üretim hızlarının sıcaklıkla değişimi

Şekil 5’te görüldüğü gibi sıcaklık artıkça hidroliz hızı da hızlı bir şekilde artmaktadır. Örneğin; $20^{\circ} \mathrm{C}$ de $\% 2 \mathrm{KBH}_{4}$ hidrolizi 40 dakikada bitmekteyken $50{ }^{\circ} \mathrm{C}$ de ise 3,5 dakikada bitmiştir. Bu durumun muhtemel nedeni artan sicaklıkla birlikte çözelti ortamında bulunan $\mathrm{KBH}_{4}$ taneciklerinin difüzyonunun artması ile ilgilidir. Ancak deneysel çalışmalar gerçekleştirildiğinde hemen bütün sıcaklıklarda hidrojen 
hacminin zamanla değişimi doğrusal olmayan bir davranış sergilemektedir. Bunun da sebebi Ni-P-B katalizörü varlığında $\mathrm{KBH}_{4}$ hidrolizinin sadece sıcaklık kontrollü olmayıp başka parametrelere de bağlı olduğunu göstermektedir. Şekil 5'in içine yerleştirilen başlangıç hızlarının sıcaklıkla değişim grafiğinde de sıcaklığın artışı ile hidrolizin hızlı bir şekilde artığını fakat doğrusal olmadığı görülmektedir.

Sonuç olarak sıcaklığın $\mathrm{KBH}_{4}$ hidrolizi üzerine oldukça etkin olduğu Şekil 5'te görülmektedir. Sıcaklığın artışı ile reaksiyon hızının hızlı bir şekilde artığını, bu da iki şekil arasında bir uyum olduğunu ve sonuçların birbirini desteklediklerini görüyoruz.

\subsection{KBH4 Hidroliz Kinetiği ve Reaksiyon Hız Mertebesi}

Farklı sıcaklıklarda $\mathrm{KBH}_{4}$ hidrolizinde Nİ-P-B katalizörü varlığında n.derecede reaksiyon modeline göre $\frac{1}{C_{A}^{n-1}}$ 'in zamanla değişim grafiği Şekil 6'da verilmiştir.

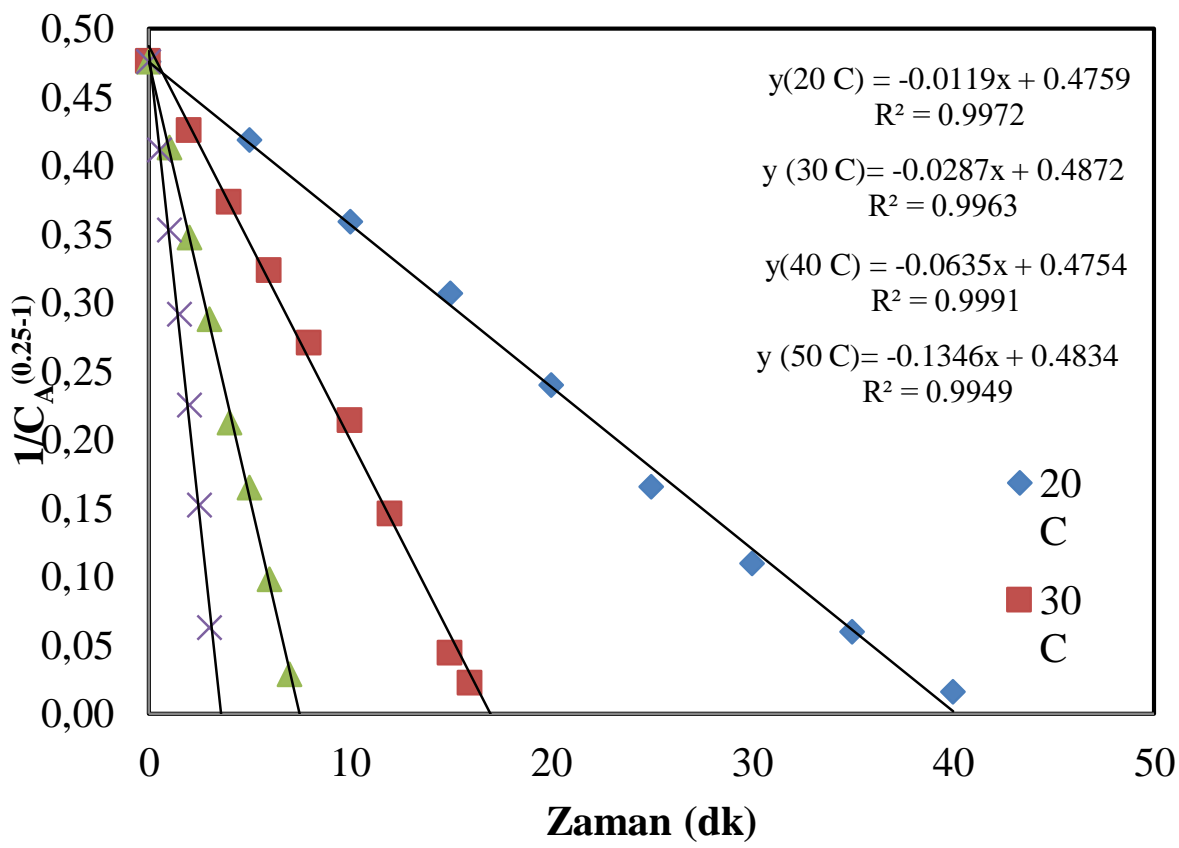

Şekil 6. Farklı sıcaklıklarda $\mathrm{KBH}_{4}$ hidrolizinde Nİ-P-B katalizörü varlığında n. derecede reaksiyon modeline göre $\frac{1}{C_{A}^{n-1}}$ 'in zamanla değişim grafiği

Şekil 6' da görüldüğü gibi bütün sıcaklıklarda seçilen (n) değeri uyumlu olup hepsi doğrusaldır. Şekil 6'da $1 / \mathrm{C}^{\mathrm{n}-1}$ 'e karşı zaman grafiğini çizmek için en uygun (n )değerini (reaksiyon hız derecesi) deneme yanılma yolu ile bulunur. Bu amaçla öncelikle 0 ile 0,99 değerleri arsında olacak şekilde bir (n) değeri başlangiçta tahmin edilir ve daha sonra $1 / \mathrm{C}^{\mathrm{n}-1}$, e karşı zaman grafiğini çizilir ve elde edilen grafikte bir doru denklemi geçirilerek reaksiyon kat sayısına bakılır. Bir sonraki adımda (n) değeri artırılarak elde edilen denklemlerin kat sayıları bulunur, en uygun reaksiyon kat sayısını (n) verene kadar ayni işleme devam edilir. Şekil 6'da verilen grafikte en uygun bütün sıcaklıkları temsil eden reaksiyon hız mertebesi 0.25 olarak bulunmuş. $\mathrm{Bu}$ reaksiyon derecesi sadece $\mathrm{KBH}_{4}$ konsantrasyonuna bağl1 derecedir. Fakat hidrolizde en etkin olan su, $\mathrm{KOH}$, ve katalizör miktarına bağlı hız eşitliğini ifade etmemektedir. Şekil 6'da farklı sıcaklıklarda elde edilen doğru denklemlerinin eğiminde her bir sicaklık için reaksiyon hız sabiti belirlendi, farklı sıcaklıklarda elde edilen bu reaksiyon hız sabitleri Arhenius eşitliğine göre değerlendirildiğinde Lnk'nin 1/T ile değişimi Şekil 7'de verilmiştir. 


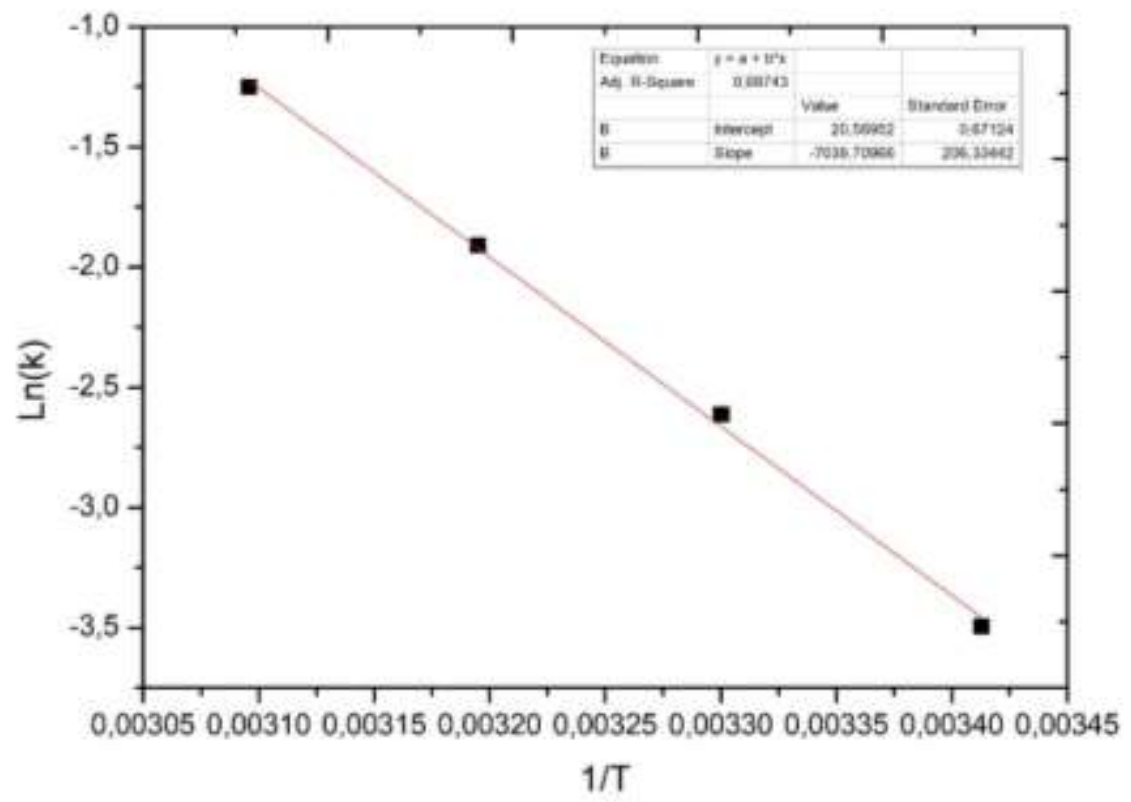

Şekil 7. Ni-P-B katalizörü varlığında $\mathrm{KBH}_{4}$ hidrolizi sonucu elde edilen reaksiyon hız sabitlerinin Arhenius eşitliğine göre değerlendirilmesi

Şekil 7'de görüldüğü gibi Lnk'nin 1/T değişimi doğrusal olup regrasyon kat sayısı da oldukça iyidir. Elde edilen doğrunun eğiminde Ni-P-B katalizörü varlığında $\mathrm{KBH}_{4}$ hidrolizi için gerekli olan aktivasyon enerjisi $\mathrm{Ea}=58.528 \mathrm{kj} / \mathrm{mol}$ olarak hesaplanmıştır.

\subsection{Ni-B-P Katalizörünün Karekterizasyonu}

Şekil 8(a)'daki SEM görüntüsünden görüldüğü gibi sentezlenen Ni-P-B katalizörünün yüzeyinin pürüzsüz olduğu ve homojen bir yüzeye sahip olduğu görülmektedir. Şekil 8(b) Ni-B-P katalizörünün XRD grafiğini göstermektedir. Şekilden görüleceği gibi Ni-P-B katalizörün $2 \theta=42^{\circ}$ ve $2 \theta=45^{\circ}$ amorf yapıda olduğu görülmektedir. Aynı zamanda katalizörün BET yüzey alanı $5.26 \mathrm{~m}^{2} / \mathrm{g}$ olduğu belirlendi.

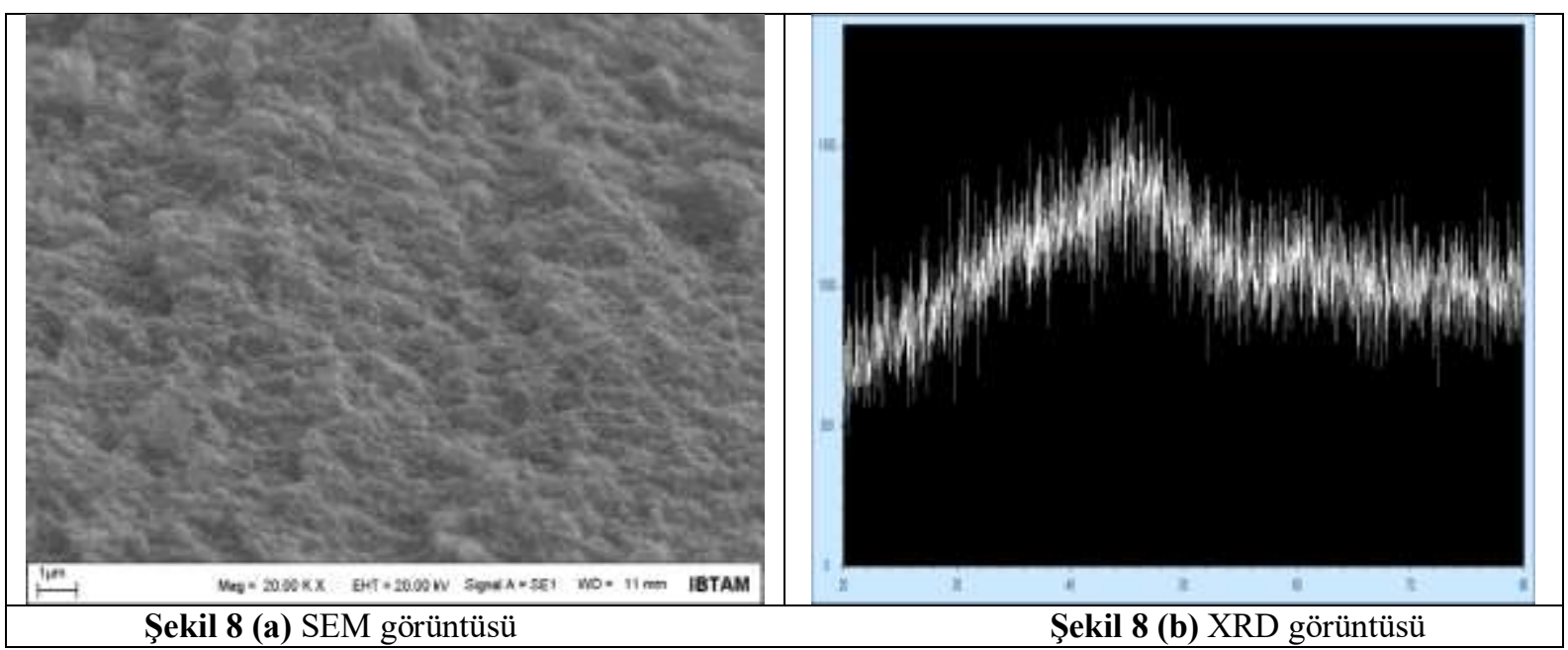

\section{Sonuç ve Öneriler}

$\mathrm{Bu}$ çalışmada daha önce potasyum bor hidrür hidrolizinde kullanılmayan Ni-B-P katalizörü sentezlendi. Burada en uygun Ni/P oranı 0.184 olarak bulundu. Ayrıca potasyum bor hidrürün hidrolizinde stabiliteyi korumak için en uygun $\mathrm{KOH}$ oran $1 \% 2.5$ optimum katalizör miktarı $50 \mathrm{mg}$ ve en uygun $\mathrm{KBH}_{4}$ oranı $\% 2$ olarak belirlendi. Buradaki en önemli noktalardan biriside farklı sıcaklıkların Ni-B-P katalizörü 
varlığında potasyum bor hidrürün hidrolizine etkisidir. Burada hidrojen üretimi yakıt pilinde kullanılmak isteniyorsa $40^{\circ} \mathrm{C}$ 'nin üzerindeki sıcaklıklarda çalış1lması daha uygun olacaktır. Çünkü zamana bağlı olarak elde edilen hidrojen hacimleri hemen hemen sabit olup yakıt pilinde üretilen enerjinin kararlılığı açısında önem arz etmektedir. Ayrıca reaksiyon derecesi 0.25 olarak ve aktivasyon enerjisi de 58.528kJ/ mol olark belirlendi. Bununla birlikte katalizörün karakterizasyonu ileri analitiksel yöntemler kullanılarak gerçekleştirildi.

\section{Teşekkür}

Bu çalışma Van YYÜ Bilimsel Araştırma Projeleri Başkanlığı tarafindan FDK-2017-6256 projesi kapsamında desteklenmiştir.

\section{Yazarların Katkısı}

Makale için hipotezin oluşturulmasına ve gerekli düzenlemelerin takip edilmesine Prof. Dr. M. Salih AĞIRTAŞ ve Prof. Dr. Ömer ŞAHİN katkı sağlamıştır. Çalışmada kullanılan katalizör üretimi ve Hidrojen üretimi için Dr. M. Salih KESKİN ve Doç. Dr. Orhan BAYTAR katkı sağlamıştır. Yürütülen teorik hesaplamalardaki sonuçların sunumuna, literatürün araştırılmasına ve makalenin yazımına Doç. Dr. Mehmet Sait İGİ katkı sağlamıştır.

\section{Çıkar Çatışması Beyanı}

Yazarlar arasında herhangi bir çıkar çatışması bulunmamaktadır.

\section{Araştırma ve Yayın Etiği Beyanı}

Yapılan çalışmada, araştırma ve yayın etiğine uyulmuştur.

\section{Kaynaklar}

[1] Zhang D., Whang J., Lin Y., Si Y., Huang C., Yang J., Huang B., Li W. 2017. Present situation and future prospect of renewable energy in China. Renew. Sustain. Energy Rev., 76: 865-871.

[2] Datta A. 2009. Modelling doped (Ni, Pd, Pt) sulfur-nitrolic systems as new motifs for storage of hydrogen. Phys. Chem. Chem. Phys., 11: 11054-11059.

[3] Tamburic B., Dechatiwongse P., Zemichael F.W., Maitland G.C., Hellgardt K. 2013. Process and reactor design for biophotolytic hydrogen production. Phys. Chem. Chem. Phys., 15: 1078310794.

[4] İzgi M.S. 2016. Effect of microwave irritated Co-B-Cr catalyst on the hydrolysis of sodium borohydride. Energy Sources, Part A Recover. Util. Environ. Eff., 38: 2590-2597.

[5] Wee J.H., Lee K.Y., Kim S.H. 2006. Sodium borohydride as the hydrogen supplier for proton exchange membrane fuel cell systems. Fuel Process. Technol., 87: 811-819.

[6] Chen B., Chen S., Bandal H., Ntiamoah R., Jadhav A., Kim H. 2018. Cobalt nanoparticles supported on magnetic core-shell structured carbon as a highly efficient catalyst for hydrogen generation from NaBH4hydrolysis. Int. J. Hydrogen Energy 43, 9296-9306.

[7] Çelik Kazici H., Yildiz F., İzgi M.S., Ulaş B., Kivrak H. 2019. Novel activated carbon supported trimetallic $\mathrm{PdCoAg}$ nanoparticles as efficient catalysts for the hydrolytic dehydrogenation of ammonia borane. Int. J. Hydrogen Energy, doi:10.1016/j.ijhydene.2019.02.198.

[8] Rakap M. 2015. Hydrolysis of Sodium Borohydride and Ammonia Borane for Hydrogen Generation Using Highly Efficient Poly(N-Vinyl-2-Pyrrolidone)-Stabilized Ru-Pd Nanoparticles as Catalysts. Int. J. Green Energy, 12: 1288-1300.

[9] Demirci U.B., Miele P. 2009. Sodium borohydride versus ammonia borane, in hydrogen storage and direct fuel cell applications. Energy Environ. Sci., 2: 627-637.

[10] Eigen N., Kunowsky M., Klassen T., Bormann R. 2007. Synthesis of NaAlH4-based hydrogen storage material using milling under low pressure hydrogen atmosphere. J. Alloys Compd., 430: 350-355. 
[11] Şahin Ö., Izgi M.S., Onat E., Saka C. 2016. Influence of the using of methanol instead of water in the preparation of $\mathrm{Co}-\mathrm{B}-\mathrm{TiO} 2$ catalyst for hydrogen production by $\mathrm{NaBH} 4 \mathrm{hydrolysis}$ and plasma treatment effect on the Co-B-TiO ${ }_{2}$ catalyst. Int. J. Hydrogen Energy, 41: 2539-2546.

[12] Zahmakiran M., Özkar S. 2009. Zeolite framework stabilized rhodium(0) nanoclusters catalyst for the hydrolysis of ammonia-borane in air: Outstanding catalytic activity, reusability and lifetime. Appl. Catal. B Environ., 89: 104-110.

[13] Fernandes R., Patel N., Miotello A. 2009. Efficient catalytic properties of Co-Ni-P-B catalyst powders for hydrogen generation by hydrolysis of alkaline solution of $\mathrm{NaBH} 4$. Int. J. Hydrogen Energy, doi:10.1016/j.ijhydene.2009.02.007.

[14] Xu Q., Chandra M. 2006. Catalytic activities of non-noble metals for hydrogen generation from aqueous ammonia-borane at room temperature. J. Power Sources, 163: 364-370.

[15] Ma Y., Li W., Zhang M., Zhou Y., Tao K. 2003. Preparation and catalytic properties of amorphous alloys in hydrogenation of sulfolene. Appl. Catal. A Gen., 243: 215-223.

[16] İzgi M.S., Şahin Ö., Ödemiş Ö., Horoz S. 2018. Microwave Treatment on Co-B-P Catalyst to Enhance Catalytic Activity for Hydrogen Production by Hydrolysis of Nabh4. Adv. Mater. Sci. Eng., 2: 2-7.

[17] İzgi M.S., Şahin Ö., Saka C. 2019. $\gamma$-Al 2 O 3 supported/Co-Cr-B catalyst for hydrogen evolution via NH 3 BH 3 hydrolysis. Mater. Manuf. Process, 1-7.

[18] Peng C.Y., Kang L., Cao S., Chen Y., Lin Z.S., Fu W.F. 2015. Nanostructured Ni2P as a Robust Catalyst for the Hydrolytic Dehydrogenation of Ammonia-Borane. Angew. Chemie-Int. Ed., 54: 15725-15729.

[19] Wei Y., Wang R., Meng L., Wang Y., Li G., Xin S., Zhao X., Zhang K. 2017. Hydrogen generation from alkaline $\mathrm{NaBH} 4$ solution using a dandelion-like $\mathrm{Co}-\mathrm{Mo}-\mathrm{B}$ catalyst supported on carbon cloth. Int. J. Hydrogen Energy, 42.

[20] İzgi M.S., Onat E., Çelik Kazici H., Şahin Ö. 2019. Hydrogen production through the cooperation of a catalyst synthesized in ethanol medium and the effect of the plasma. Energy Sources, Part A: Recovery, Utilization, and Environmental Effects, 1-14.

[21] Zhang J., Chen C., Chen S., Hu Q., Gao Zhe., Li Y., Qin Y. 2017. Highly dispersed Pt nanoparticles supported on carbon nanotubes produced by atomic layer deposition for hydrogen generation from hydrolysis of ammonia borane. Catal. Sci. Technol., 7: 322-329.

[22] Baytar O., Horoz S., Nar S. 2019. $\mathrm{Al}_{2} \mathrm{O}_{3}$ supported Co-Cu-B $\left(\mathrm{Co}-\mathrm{Cu}-\mathrm{B} / \mathrm{Al}_{2} \mathrm{O}_{3}\right)$ catalyst for hydrogen generation by hydrolysis of aqueous sodium borohydride. Digest Journal of Nanomaterials and Biostructures., 14: 673-681. 